\title{
Quantitative and qualitative analysis of alkaloids composition in the seeds of a white lupin (Lupinus albus $\mathbf{L}$.) collection
}

\author{
Magdalena Kroc • Wojciech Rybiński • Paulina Wilczura • Katarzyna Kamel • \\ Zygmunt Kaczmarek • Paweł Barzyk • Wojciech Święcicki
}

Received: 12 July 2016/ Accepted: 7 November 2016/Published online: 26 November 2016

(C) The Author(s) 2016. This article is published with open access at Springerlink.com

\begin{abstract}
White lupin (Lupinus albus L.) has unexploited potential as a crop plant due to its high seed yield as well as protein and oil content in seeds. Wellcharacterized collections of gene resources are very important for breeding as a source of genetic variation. This paper presents the results of analyses for total content and qualitative composition of alkaloids in seeds of 367 L. albus accessions from the Polish Genebank. Accessions were divided into four classes of origin: wild collected material, land races, breeding lines, and cultivars. Apart from the expected broad variation as well as strong differentiation in the alkaloid content, a clear influence of domestication was observed. This was shown as an apparent decrease in the alkaloid content in
\end{abstract}

M. Kroc · W. Rybiński · P. Wilczura ·

K. Kamel · W. Święcicki $(\bowtie)$

Department of Genomics, Institute of Plant Genetics,

Polish Academy of Sciences, Strzeszynska 34,

60-479 Poznan, Poland

e-mail: wswi@igr.poznan.pl

Z. Kaczmarek

Department of Biometry and Bioinformatics, Institute of Plant Genetics, Polish Academy of Sciences, Strzeszynska 34, 60-479 Poznan, Poland

P. Barzyk

Poznan Plant Breeders Ltd, Wiatrowo Plant Breeding

Branch, 62-100 Wagrowiec, Poland breeding lines and cultivars classes. The total alkaloid content varies from 0.02 to $12.73 \%$ of the seed dry weight. Six major alkaloids (abundance $>1 \%$ ) were revealed: lupanine $(28.22-94.49 \%$, mean $76.06 \%$ in total content), 13-hydroxylupanine $(0.10-32.78 \%$, mean $8.23 \%)$, multiflorine $(0.00-21.67 \%$, mean $5.52 \%)$, albine $(0.00-18.55 \%$, mean $4.48 \%)$, angustifoline $(0.24-12.14 \%$, mean $2.07 \%)$, 11,12-seco-12,13didehydromultiflorine (0.00-12.28\%, mean $1.74 \%)$. Owing to its abundance, lupanine was found to be the most closely correlated to the total alkaloid content.

Keywords Alkaloids - Anti-nutritive compounds . Genetic resources · Lupinus albus · White lupin

\section{Introduction}

The genus Lupinus covers 275 species encompassing mostly small-seeded New World species (largeseeded L. mutabilis Sweet being an exception) and 13-15 large-seeded species of the Old World, including three lupin crops-L. albus L., L. angustifolius L., and L. luteus L. (Cardoso et al. 2013; Cowling et al. 1998a; Pascual 2004; Święcicki et al. 1996, 2001). Apart from its own environmental requirements, each lupin crop has potential benefits in feeding and farming (Brummund and Święcicki 2011).

White lupin originates from the Mediterranean area and has been cultivated since ancient times in 
Greece (Kurlovich 2002). According to Harrison and Williams (1982) the wild forms of $L$. albus contain a high level of quinolizidine alkaloids in seeds-up to $2.2 \%$ of the seed dry weight (DW), whereas cultivars with the gene reducing alkaloid content: pauper, possess $0.02-0.05 \%$ of the seed DW. Like other lupin crops L. albus plant architecture is adapted to modern cropping technologies (Górynowicz et al. 2014). Apart from the advantages common to other lupins it is also characterized by outstanding oil content in seeds (up to 14\%) and the highest seed yield (Brummund and Święcicki 2011). Given these facts, white lupin has a potential as a protein plant, provided that further improvements be achieved with regard to resistance to anthracnose, earliness, and alkaloid content in seeds (Cowling et al. 1998b; Święcicki et al. 2015). Decreasing the alkaloid content in breeding as a basic requirement to use lupins as fodder has been precisely described in literature (Brummund and Święcicki 2011; Hackbarth and Troll 1956; Kamel et al. 2016).

At least five loci controlling alkaloid content are present in L. albus (Harrison and Williams 1982) and the one with pauper gene is the most effective in reducing alkaloid content and thus most frequently used in breeding (Lin et al. 2009). Cultivars possessing pauper gene contain $0.02-0.05 \%$ alkaloids of the seed DW (Harrison and Williams 1982; Święcicki et al. 2015) with following qualitative composition of major alkaloids (abundance $>1 \%$ ): lupanine-70\%, albine-15\%, 13-hydroxylupanine- $8 \%$, and multiflorine-3\% (Wink et al. 1995). Earlier investigation on the narrow-leafed lupin collection revealed a broad variation of the total alkaloid content in seeds from 0.0005 to $2.88 \%$ of the seed DW (Kamel et al. 2016). It was stated that numerous cultivars are characterized by safely low alkaloid content $(<0.02 \%$ of the seed DW) (Cowling et al. 1998a), but in genetic resources there are accessions with clearly lower content, useful for further cultivar improvement.

About 14,000 of accessions are gathered in Lupinus collections worldwide (Święcicki et al. 2015). Some of them are well described and characterized (Cowling et al. 1998a; Święcicki et al. 2000). To improve the value of gene resources as an initial breeding material, a precise valorization is important. Therefore, the aim of this study was to evaluate total contents and qualitative compositions of alkaloids in seeds of the Polish collection of $L$. albus.

\section{Materials and methods}

Plant material

A total of 367 accessions of white lupin from the Polish Lupinus Gene Bank, Wiatrowo (Poznan Plant Breeders Ltd.), were investigated. Among accessions studied, also included were cvs. Feli (Wt95 531) and Nelly (Wt95 480) as the International Union for the Protection of New Varieties of Plants (UPOV) controls for high and low alkaloid content (UPOV 2004). The investigated plant materials belong to four classes of different origins:

- CO-180 wild lines and primitive populations originated from places of natural distribution and collecting missions,

- LR-74 land races,

- XD-54 breeding lines,

- $\mathrm{CV}-59$ present and old cultivars.

Accessions were sown for regeneration in the field experiment in Wiatrowo, Poland (latitude $52^{\circ} 45^{\prime} 9^{\prime \prime} \mathrm{N}$; longitude $17^{\circ} 8^{\prime} 36^{\prime \prime} \mathrm{E}$; altitude $86 \mathrm{~m}$ above sea level) in 2014 in a completely randomized design in two replications (plot size $1 \mathrm{~m}^{2}, 60$ seeds per plot). Seed samples for analyses were collected from each plot after full maturity.

Total alkaloid content and individual alkaloids composition were evaluated by gas chromatography. The extraction and analyses were conducted following the procedure presented by Kamel et al. (2016).

\section{Statistical analyses}

The one-factor analysis of variance was applied for testing hypotheses concerning the differences between means from four classes of origin and significant differences between accessions inside individual characters (total and individual alkaloid contents) for each class. Testing differences between accessions were made on the basis of significance level $P=0.01$. Moreover, for the total alkaloids content, individual alkaloids content, and four classes of origin the Gabriel procedure was used (Gabriel 1964). It divided the set of accessions in each class into three homogenous groups concerning alkaloid content (high, medium, and low) with the means significantly differentiated. As a measure of the linear dependence between the total content of alkaloids and its six 
components (individual alkaloids), the correlation coefficients were calculated.

\section{Results and discussion}

The table presenting results of total alkaloid content (\% of the seed DW) and qualitative composition of six major alkaloids (\% of the seed DW and its \% in total alkaloid content) of all investigated $L$. albus

Table 1 Total alkaloid contents and qualitative composition of the major alkaloids in seeds of the L. albus collection (I-in all classes of origin-367 accessions, II-in the CO and CV class, accessions is placed online at: http://www.igr. poznan.pl/uploads/resources/Lupinus\%20albus.pdf.

A very broad variation was obtained for the total as well as individual alkaloid content (Table 1-I). Total alkaloid content varied from 0.016 to $12.73 \%$ of the seed DW (mean $2.47 \%$ ). Thus, the maximum contents found in $L$. albus clearly exceed those reported for $L$. angustifolius (Kamel et al. 2016). A comparison of mean values as well as minimum and maximum values in $\mathrm{CO}$ and $\mathrm{CV}$ classes (Table 1-II) shows evident

III - in accessions with minimum and maximum value of a given character/bold)

\begin{tabular}{|c|c|c|c|c|c|c|c|c|}
\hline \multirow[t]{2}{*}{ Part } & \multirow[t]{2}{*}{ Values } & \multicolumn{7}{|l|}{ Character } \\
\hline & & $\begin{array}{l}\text { Total } \\
\text { alkaloid } \\
\text { content } \\
\text { (\% of the } \\
\text { seed } \\
\text { DW) }\end{array}$ & $\begin{array}{l}\text { Lupanine } \\
\text { (\% of } \\
\text { total) }\end{array}$ & $\begin{array}{l}13- \\
\text { hydroxylupanine } \\
\text { (\% of total) }\end{array}$ & $\begin{array}{l}\text { Multiflorine } \\
\text { (\% of total) }\end{array}$ & $\begin{array}{l}\text { Albine } \\
\text { (\% of } \\
\text { total) }\end{array}$ & $\begin{array}{l}\text { Angustifoline } \\
\text { (\% of total) }\end{array}$ & $\begin{array}{l}11,12 \text {-seco- } 12,13- \\
\text { didehydromultiflorine } \\
(\% \text { of total })\end{array}$ \\
\hline \multirow[t]{3}{*}{ I } & Mean & 2.47 & 76.06 & 8.23 & 5.52 & 4.48 & 2.07 & 1.74 \\
\hline & Minium & 0.02 & 28.22 & 0.10 & 0.00 & 0.00 & 0.24 & 0.00 \\
\hline & Maximum & 12.73 & 94.49 & 32.78 & 21.67 & 18.55 & 12.14 & 12.28 \\
\hline \multirow[t]{7}{*}{ II } & $\mathrm{CO}$ & & & & & & & \\
\hline & Mean & 3.05 & 78.91 & 6.04 & 6.01 & 4.43 & 1.72 & 1.50 \\
\hline & Minium & 0.06 & 53.87 & 0.25 & 0.00 & 0.00 & 0.26 & 0.10 \\
\hline & $\begin{array}{l}\text { Maximum } \\
\mathrm{CV}\end{array}$ & 12.73 & 94.49 & 22.50 & 18.07 & 18.55 & 7.24 & 5.74 \\
\hline & Mean & 1.36 & 72.30 & 10.89 & 4.91 & 4.29 & 2.56 & 1.98 \\
\hline & Minium & 0.02 & 28.22 & 2.35 & 1.01 & 0.02 & 0.29 & 0.20 \\
\hline & Maximum & 4.91 & 92.82 & 32.78 & 21.67 & 16.41 & 10.15 & 12.28 \\
\hline \multirow[t]{14}{*}{ III } & Accession/class & & & & & & & \\
\hline & Wt $95413 / \mathrm{CV}$ & 0.02 & 59.28 & 24.10 & 2.14 & 3.52 & 4.13 & 0.94 \\
\hline & Wt 95015/CO & 12.73 & 87.12 & 1.15 & 5.62 & 3.98 & 0.50 & 0.65 \\
\hline & Wt $95449 / \mathrm{CV}$ & 0.04 & 28.22 & 31.72 & 1.99 & 16.41 & 10.15 & 0.63 \\
\hline & Wt 95099/CO & 3.29 & 94.49 & 2.16 & 1.63 & & 0.40 & 0.19 \\
\hline & Wt 95115/LR & 3.44 & 88.58 & 0.10 & 2.79 & 6.65 & 0.47 & 0.32 \\
\hline & Wt $95431 / \mathrm{CV}$ & 0.02 & 34.01 & 32.78 & 2.50 & 8.99 & 8.35 & 4.56 \\
\hline & Wt 95175/LR & 0.05 & 31.57 & 32.08 & 0.00 & 15.66 & 12.14 & 0.00 \\
\hline & $\begin{array}{l}\text { Wt 95531/CV } \\
\text { (Feli) }\end{array}$ & 3.14 & 67.45 & 3.99 & 21.67 & 0.02 & 1.83 & 3.49 \\
\hline & Wt $95608 / \mathrm{CO}$ & 9.08 & 87.97 & 3.13 & 7.51 & 0.02 & 0.45 & 0.34 \\
\hline & Wt $95054 / \mathrm{CO}$ & 2.92 & 60.46 & 6.13 & 6.28 & 18.55 & 3.32 & 3.91 \\
\hline & Wt 95090/CO & 3.43 & 93.93 & 2.59 & 1.34 & 0.21 & 0.26 & 0.25 \\
\hline & Wt 95175/LR & 0.05 & 31.57 & 32.08 & 0.00 & 15.66 & 12.14 & 0.00 \\
\hline & $\begin{array}{l}\text { Wt 95480/CV } \\
\text { (Nelly) }\end{array}$ & 0.10 & 51.67 & 19.99 & 3.42 & 0.22 & 4.74 & 12.28 \\
\hline
\end{tabular}


breeding successes in the white lupin. Nevertheless, it is also possible to find low alkaloid accessions in $\mathrm{CO}$ class and vice versa-bitter accessions in CV class. It is worth mentioning that genotypes with the lowest alkaloid content belonged not only to CV class (Kijewskij Mutant- $0.016 \%$ of the seed DW), but also XD (Bialorus- $1-0.016 \%$ of the seed DW) and LR (P. $21525-0.017 \%$ of the seed DW) class. Overall exploitation of these results might be useful in broadening the Lupinus albus breeding gene pool.

In an earlier investigation of alkaloid pattern in the white lupin seeds, four major alkaloids were discovered (abundance $>1 \%$ of total alkaloids): lupanine, albine, 13-hydroxylupanine, and multiflorine (Wink et al. 1995). The results of our studies revealed six major alkaloids in primitive $(\mathrm{CO}+\mathrm{LR})$ as well as improved accessions (XD $+\mathrm{CV}$ ) (Table 1). These were lupanine (mean $76.06 \%$ of total alkaloids), 13-hydroxylupanine $(8.23 \%)$, multiflorine $(5.52 \%)$, albine (4.48\%), angustifoline (2.07\%), and 11,12seco-12,13-didehydromultiflorine (1.74\%). Additionally, a seventh alkaloid-ammodendrine-with mean content $1.01 \%$ was detected, which eventually was not considered in the analyses as it was absent in numerous accessions. Among all major alkaloids, the one always present and clearly dominating was lupanine (28.22-94.49\% of total alkaloids). At the same time, other major alkaloids were found in high proportions in some accessions (e.g., maximum for 13-hydroxylupanine-32.78\%, multiflorine-21.67\%), while in very low proportions or absent in others (13hydroxylupanine $-0.10 \%$ and multiflorine $-0.00 \%$, respectively). This shows that a clear-cut division into major and minor alkaloids is rather difficult. In the earlier analysis of narrow-leafed lupin alkaloids, different qualitative compositions of major alkaloids were obtained (mean \% of total alkaloids): lupanine-46.4\%, 13-hydroxylupanine-35.6\%, angustifoline $-15.5 \%$, and isolupanine-2.5\% (Kamel et al. 2016).

In Table 1-III, a qualitative composition of alkaloids is presented for accessions characterized with the lowest and the highest content of total and individual alkaloids (in bold). In the accession Wt95015, distinguished with the highest total alkaloid content, lupanine dominated, and the contribution of other alkaloids was clearly low. In the case of the accession Wt95413, with the lowest total alkaloid content, a lower share of lupanine that was mainly supplemented by 13-hydroxylupanine was observed. The most apparent example of complementation was the accession Wt95431, where clearly higher share of 13-hydroxylupanine went along with decreased lupanine content; this tendency was seen in most of the accessions. No clear pattern of complementation was noticeable in the case of accessions with increased contribution of remaining alkaloids [multiflorine (Wt95531), albine (Wt95054), angustifoline (Wt95175), and 11,12-seco-12,13-didehydromultiflorine (Wt95480)]; however, in all cases lupanine or lupanine +13 -hydroxylupanine obviously dominated.

Significant differences among accessions from four classes of origin considering mean values of total and individual alkaloid content were determined by one-

Table 2 Mean values for alkaloids in four classes of origin

\begin{tabular}{|c|c|c|c|c|c|}
\hline \multirow[t]{2}{*}{ Character } & \multicolumn{5}{|c|}{ Class of origin } \\
\hline & $\overline{\mathrm{F}_{\text {calc }}^{2}}$ & $\mathrm{CO}$ & LR & $\mathrm{XD}$ & $\mathrm{CV}$ \\
\hline Total alkaloid content & $73.11^{* *}$ & $3.053 \mathrm{a}^{1}$ & $2.789 \mathrm{a}$ & $1.316 \mathrm{~b}$ & $1.359 \mathrm{~b}$ \\
\hline Lupanine & $69.30 * *$ & $2.427 \mathrm{a}$ & $2.184 b$ & $0.970 \mathrm{c}$ & $1.074 \mathrm{c}$ \\
\hline Multiflorine & $24.90 * *$ & $0.188 \mathrm{a}$ & $0.171 \mathrm{a}$ & $0.081 b$ & $0.090 \mathrm{~b}$ \\
\hline 13-hydroxylupanine & $25.46^{* *}$ & $0.173 \mathrm{a}$ & $0.178 \mathrm{a}$ & $0.122 b$ & $0.084 \mathrm{c}$ \\
\hline Albine & $24.78 * *$ & $0.132 \mathrm{a}$ & $0.123 \mathrm{a}$ & $0.065 b$ & $0.046 \mathrm{~b}$ \\
\hline Angustifoline & $21.25 * *$ & $0.050 \mathrm{a}$ & $0.054 \mathrm{a}$ & $0.032 b$ & $0.022 \mathrm{~b}$ \\
\hline 11,12-seco-12,13-didehydromultiflorine & $21.87 * *$ & $0.044 \mathrm{a}$ & $0.045 \mathrm{a}$ & $0.025 b$ & $0.020 \mathrm{~b}$ \\
\hline
\end{tabular}


Table 3 Accessions division into three homogenous groups within L. albus individual classes of origin for total alkaloid content and content of major alkaloids (\% of the seed DW)

\begin{tabular}{|c|c|c|c|c|c|c|}
\hline \multirow[t]{2}{*}{ Alkaloid } & \multirow[t]{2}{*}{ Group $^{a}$} & \multirow[t]{2}{*}{ Results } & \multicolumn{4}{|c|}{ Class of origin } \\
\hline & & & $\mathrm{CO}$ & LR & $\mathrm{XD}$ & $\mathrm{CV}$ \\
\hline \multirow[t]{9}{*}{ Total } & \multirow[t]{3}{*}{1} & Number of accessions & 3 & 10 & 5 & 6 \\
\hline & & Content & $9.08-12.73$ & $4.30-8.21$ & $3.30-4.30$ & $3.13-4.91$ \\
\hline & & Mean & 10.53 & 5.23 & 3.96 & 3.87 \\
\hline & \multirow[t]{3}{*}{2} & Number of accessions & 68 & 38 & 16 & 23 \\
\hline & & Content & $3.15-6.45$ & $2.31-3.96$ & $1.45-3.08$ & $1.21-2.73$ \\
\hline & & Mean & 3.80 & 3.12 & 2.37 & 1.93 \\
\hline & \multirow[t]{3}{*}{3} & Number of accessions & 109 & 26 & 33 & 30 \\
\hline & & Content & $0.07-3.10$ & $0.02-2.15$ & $0.02-1.27$ & $0.02-1.10$ \\
\hline & & Mean & 2.29 & 1.37 & 0.40 & 0.42 \\
\hline \multirow[t]{9}{*}{ Lupanine } & \multirow[t]{3}{*}{1} & Number of accessions & 3 & 3 & 13 & 5 \\
\hline & & Content & $7.98-11.09$ & $4.27-7.05$ & $1.93-3.39$ & $2.81-4.30$ \\
\hline & & Mean & 9.20 & 5.49 & 2.44 & 3.36 \\
\hline & \multirow[t]{3}{*}{2} & Number of accessions & 64 & 40 & 10 & 17 \\
\hline & & Content & $2.48-5.36$ & $1.97-3.82$ & $0.81-1.79$ & $1.16-2.46$ \\
\hline & & Me an & 3.24 & 2.72 & 1.27 & 1.79 \\
\hline & \multirow[t]{3}{*}{3} & Number of accessions & 113 & 31 & 31 & 37 \\
\hline & & Content & $0.04-2.42$ & $0.01-1.87$ & $0.01-0.60$ & $0.01-1.09$ \\
\hline & & Mean & 1.88 & 1.18 & 0.25 & 0.44 \\
\hline \multirow[t]{9}{*}{ 13-hydroxylupanine } & \multirow[t]{3}{*}{1} & Number of accessions & 18 & 11 & 2 & 6 \\
\hline & & Content & $0.28-0.36$ & $0.33-0.60$ & $0.40-0.51$ & $0.18-0.30$ \\
\hline & & Mean & 0.40 & 0.44 & 0.46 & 0.22 \\
\hline & \multirow[t]{3}{*}{2} & Number of accessions & 56 & 21 & 13 & 21 \\
\hline & & Content & $0.17-0.21$ & $0.16-0.30$ & $0.19-0.34$ & $0.08-0.15$ \\
\hline & & Mean & 0.22 & 0.22 & 0.26 & 0.12 \\
\hline & \multirow[t]{3}{*}{3} & Number of accessions & 106 & 42 & 39 & 32 \\
\hline & & Content & $0.01-0.14$ & $0.00-0.15$ & $0.00-0.14$ & $0.00-0.07$ \\
\hline & & Mean & 0.11 & 0.09 & 0.06 & 0.04 \\
\hline \multirow[t]{9}{*}{ Multiflorine } & \multirow[t]{3}{*}{1} & Number of accessions & 20 & 7 & 5 & 2 \\
\hline & & Content & $0.38-0.68$ & $0.44-0.82$ & $0.31-0.40$ & $0.46-0.68$ \\
\hline & & Mean & 0.50 & 0.57 & 0.37 & 0.57 \\
\hline & \multirow[t]{3}{*}{2} & Number of accessions & 61 & 23 & 11 & 11 \\
\hline & & Content & $0.18-0.31$ & $0.16-0.37$ & $0.11-0.22$ & $0.14-0.34$ \\
\hline & & Mean & 0.24 & 0.24 & 0.15 & 0.23 \\
\hline & \multirow[t]{3}{*}{3} & Number of accessions & 99 & 44 & 38 & 46 \\
\hline & & Content & $0.00-0.15$ & $0.00-0.15$ & $0.00-0.08$ & $0.00-0.13$ \\
\hline & & Mean & 0.09 & 0.07 & 0.02 & 0.03 \\
\hline \multirow[t]{9}{*}{ Albine } & \multirow[t]{3}{*}{1} & Number of accessions & 20 & 12 & 5 & 9 \\
\hline & & Content & $0.30-0.56$ & $0.28-0.44$ & $0.24-0.36$ & $0.11-0.23$ \\
\hline & & Mean & 0.39 & 0.33 & 0.30 & 0.16 \\
\hline & 2 & Number of accessions & 61 & 17 & 11 & 21 \\
\hline & & Content & $0.12-0.20$ & $0.12-0.25$ & $0.07-0.17$ & $0.03-0.10$ \\
\hline & & Mean & 0.19 & 0.19 & 0.12 & 0.05 \\
\hline & 3 & Number of accessions & 99 & 45 & 38 & 29 \\
\hline & & Content & $0.00-0.06$ & $0.00-0.11$ & $0.00-0.06$ & $0.00-0.01$ \\
\hline & & Mean & 0.05 & 0.04 & 0.02 & 0.00 \\
\hline
\end{tabular}


Table 3 continued

\begin{tabular}{|c|c|c|c|c|c|c|}
\hline \multirow[t]{2}{*}{ Alkaloid } & \multirow[t]{2}{*}{ Group $^{a}$} & \multirow[t]{2}{*}{ Results } & \multicolumn{4}{|c|}{ Class of origin } \\
\hline & & & $\mathrm{CO}$ & LR & $\mathrm{XD}$ & $\mathrm{CV}$ \\
\hline \multirow[t]{9}{*}{ Angustifoline } & \multirow[t]{3}{*}{1} & Number of accessions & 24 & 14 & 5 & 9 \\
\hline & & Content & $0.09-0.20$ & $0.10-0.19$ & $0.11-0.19$ & $0.05-0.10$ \\
\hline & & Mean & 0.12 & 0.14 & 0.14 & 0.06 \\
\hline & \multirow[t]{3}{*}{2} & Number of accessions & 58 & 20 & 10 & 17 \\
\hline & & Content & $0.06-0.08$ & $0.04-0.10$ & $0.04-0.09$ & $0.02-0.04$ \\
\hline & & Mean & 0.07 & 0.07 & 0.06 & 0.03 \\
\hline & \multirow[t]{3}{*}{3} & Number of accessions & 98 & 40 & 39 & 33 \\
\hline & & Content & $0.004-0.04$ & $0.00-0.04$ & $0.00-0.03$ & $0.00-0.02$ \\
\hline & & Mean & 0.02 & 0.02 & 0.01 & 0.01 \\
\hline \multirow{9}{*}{$\begin{array}{l}\text { 11,12-seco-12,13- } \\
\text { didehydromultiflorine }\end{array}$} & \multirow[t]{3}{*}{1} & Number of accessions & 11 & 9 & 5 & 3 \\
\hline & & Content & $0.10-0.21$ & $0.09-0.16$ & $0.07-0.11$ & $0.07-0.11$ \\
\hline & & Mean & 0.14 & 0.12 & 0.09 & 0.09 \\
\hline & \multirow[t]{3}{*}{2} & Number of accessions & 59 & 35 & 14 & 18 \\
\hline & & Content & $0.04-0.10$ & $0.03-0.08$ & $0.03-0.06$ & $0.02-0.05$ \\
\hline & & Mean & 0.07 & 0.05 & 0.04 & 0.04 \\
\hline & \multirow[t]{3}{*}{3} & Number of accessions & 110 & 30 & 35 & 38 \\
\hline & & Content & $0.00-0.04$ & $0.00-0.03$ & $0.00-0.02$ & $0.00-0.02$ \\
\hline & & Mean & 0.02 & 0.01 & 0.01 & 0.01 \\
\hline
\end{tabular}

${ }^{a}$ Group 1-high content of total/individual alkaloids, group 2-medium content, group 3-low content

Table 4 Correlation coefficients between total alkaloid content and the content of individual alkaloids in four classes of origin

\begin{tabular}{|c|c|c|c|c|c|c|}
\hline \multirow[t]{2}{*}{ Class of origin } & \multicolumn{6}{|l|}{ Alkaloid } \\
\hline & Lupanine & $\begin{array}{l}13- \\
\text { hydroxylupanine }\end{array}$ & Multiflorine & Albine & Angustifoline & $\begin{array}{l}\text { 11,12-seco-12,13- } \\
\text { didehydromultiflorine }\end{array}$ \\
\hline $\mathrm{CO}$ & $0.975 * *$ & $0.350 * *$ & $0.664 * *$ & $0.415 * *$ & $0.334 * *$ & $0.396 * *$ \\
\hline LR & $0.967 * *$ & $0.498 * *$ & $0.672 * *$ & $0.626 * *$ & $0.569 * *$ & $0.533 * *$ \\
\hline XD & $0.987 * *$ & $0.886^{* *}$ & $0.779 * *$ & $0.795 * *$ & $0.839 * *$ & $0.815 * *$ \\
\hline $\mathrm{CV}$ & $0.988 * *$ & $0.699 * *$ & $0.772 * *$ & $0.493 * *$ & $0.665^{* *}$ & $0.591 * *$ \\
\hline
\end{tabular}

** $P<0.01$

factor analysis of variance. Rejection of the null hypothesis (F-test) allowed us to compare a substantiality of differences between classes using the Neuman-Keuls test (Table 2). Given total alkaloid content, the $\mathrm{CO}$ and LR classes differed significantly from XD and CV classes. Similar pairing was observed in the case of multiflorine, albine, angustifoline, and 11,12-seco-12,13-didehydromultiflorine. This is in accordance with the domestication process affecting XD and CV classes of white lupin. In the case of other two alkaloids, different grouping was observed. Considering lupanine, a pair of XD and CV classes differed substantially from $\mathrm{CO}$ as well as LR class. Whereas for 13-hydroxylupanine, CO and LR classes paired and differed from $\mathrm{XD}$ as well as $\mathrm{CV}$ class.

In each class, significant differentiation of accessions was also detected considering all the investigated characters. Accessions were designated into three homogenous groups within each class of origin: group 1-high content of total/individual alkaloids, group 2-medium content, and group 3-low content (Table 3). In each class, the least populated was the group with the highest content of both total and individual alkaloids. Most of the accessions belonged to the second and third groups. Clearly, the most populated was the group with the lowest values of all analysed characters in the CO class. This shows high 
potential of wild accessions as the rich source of low alkaloid material. In all classes of origin, accessions considered as bitter, in terms of food safety, were found in both groups 1 and 2. Low alkaloid accessions were present only in the third group, and this was also applied to the wild accessions of CO and LR class. Taking into consideration the mean value of total alkaloid content for each group, only the third group of $\mathrm{XD}$ and CV classes is clearly sweet. This fact points out the achievements of white lupin breeding. It is worth to mention that UPOV control cultivars have the following alkaloid content in the seed DW: bitter Feli (Wt95531)-3.14\% and sweet Nelly (Wt95480)$0.09 \%$.

In the case of lupanine, the main white lupin alkaloid (mean value-76.06\%, Table 1), similar tendency in diversification within the classes of origin was observed (Table 3). For the remaining alkaloids characterized with clearly lower share in total alkaloid level (mean content $1.74-8.23 \%$ of the seed DW, Table 1), it is possible to observe a systematic decrease of the content in more domesticated material that is especially noticeable when comparing group 3 (low content) of CO and LR classes versus CV class.

The influence of a content of individual alkaloids on the total alkaloid content in seed dry weight was also analysed. Correlation coefficients between total and individual alkaloids content for each class were calculated. All appeared to be substantial at least on a level 0.01 (Table 4). In each class, not surprisingly, the most correlated alkaloid with the total alkaloid content was lupanine, as its contribution is always the highest. Additionally, there were examples of alkaloids with a lower share in total content also being strongly correlated (e.g., 13-hydroxylupanine, multiflorine, albine, angustifoline, and 11,12-seco-12,13didehydromultiflorine in XD class). It can also be noticed that correlation coefficients in most cases were higher in XD and CV class in comparison to primitive $\mathrm{CO}$ and LR classes.

\section{Conclusions}

Conducted analysis of the total alkaloid content and a qualitative composition in seeds of the Polish collection of L. albus presents a very broad variation and strong differentiation of gathered accessions, much broader than hitherto described for this species and also in comparison to other lupin species (Kamel et al. 2016; Wink et al. 1995). Comparison of the results obtained in individual classes of origin showed a strong influence of domestication and breeding, which resulted in decreased content of alkaloids. Only accessions from the third group of XD and CV class can be considered as significantly low alkaloid.

Six major alkaloids (abundance $>1 \%$ ) were revealed in comparison to four described earlier. The dominating alkaloid was lupanine (mean $76.06 \%$ ) and the share of remaining was from 1.74 to $8.23 \%$. To name these alkaloids as "major" was not always proper, as quite often they show very low or even trace content. Moreover, the lupanine, thanks to a very high share, appeared to be the most correlated with the total alkaloid content.

A very high contribution of lupanine (even about 95\%) cannot be considered as species-specific, as its share was also high in earlier investigations on narrow-leafed lupin (about 73\%). Helpful in both species discrimination could be a qualitative composition of alkaloids. Among six major alkaloids revealed in seeds of the white lupin, multiflorine, albine, and 11,12-seco-12,13-didehydromultiflorine were not present in narrow-leafed lupin.

\section{Compliance with ethical standards}

Conflict of interest The authors declare that they have no conflict of interest.

Open Access This article is distributed under the terms of the Creative Commons Attribution 4.0 International License (http:// creativecommons.org/licenses/by/4.0/), which permits unrestricted use, distribution, and reproduction in any medium, provided you give appropriate credit to the original author(s) and the source, provide a link to the Creative Commons license, and indicate if changes were made.

\section{References}

Brummund M, Święcicki WK (2011) The recent history of lupin in agriculture. In: Naganowska B, Wolko B, Kachlicki P (eds) Lupin crops - an opportunity for today, a promise for the future. In: 13th international Lupin conference, Poznań, Poland, 6-10 June. International Lupin Association, Canterbury, New Zealand, pp 15-23

Cardoso D, Pennington RT, de Queiroz LP, Boatwright JS, Van Wyk BE, Wojciechowski MF, Lavin M (2013) Reconstructing the deep-branching relationships of the papilionoid legumes. S Afr J Bot 89:58-75

Cowling WA, Buirchell BJ, Tapia ME (1998a) Lupin. Lupinus L. Promoting the conservation and use of underutilized and 
neglected crops. 23. International Board for Plant Genetic Resources (IBPGR), Rome

Cowling WA, Huyghe C, Święcicki W (1998b) Lupin Breeding. In: Gladstones JS, Atkins CA, Hamblin J (eds) Lupins as crop plants: biology, production, and utilization. CAB International, Wallingford, pp 93-120

Gabriel KR (1964) A procedure for testing the homogeneity of all sets of means in analysis of variance. Biometrics 20:459-477

Górynowicz B, Święcicki W, Osiecka A, Kaczmarek Z (2014) Terminal inflorescence and restricted branching genes in lupins (L. albus L., L. angustifolius L., L. luteus L.) and field bean (Vicia faba L.) breeding in Poland. J Agric Sci Technol B4:712-721

Hackbarth I, Troll HJ (1956) Lupins as grain legumes and fodder crops. In: Handbuch der Pflanzenzüchtung, vol 4. Verlag Paul Parey, Berlin, pp 1-51 (in German)

Harrison JEM, Williams W (1982) Genetical control of alkaloids in Lupinus albus. Euphytica 31:357-364

Kamel KA, Święcicki W, Kaczmarek Z, Barzyk P (2016) Quantitative and qualitative content of alkaloids in seeds of a narrow-leafed lupin (Lupinus angustifolius L.) collection. Genet Resour Crop Evol 63:711-719

Kurlovich BS (2002) Lupins (Geography, classification, genetic resources and breeding). OY International North Express, St. Petersburg

Lin R, Renshaw D, Luckett D, Clements J, Yan G, Adhikari K, Buirchell B, Sweetingham M, Yang H (2009) Development of a sequence-specific PCR marker linked to the gene "pauper" conferring low-alkaloids in white lupin (Lupinus albus L.) for marker assisted selection. Mol Breed 23:153-161

Pascual H (2004) Lupinus mariae-josephi (Fabaceae), nueva y sopredente especie descubierta en Espana [Lupinus mariae-josephi (Fabaceae), new and surprising species discovered in Spain]. Anales del Jardin Botanica de Madrid 61:69-72

Święcicki W, Święcicki WK, Wolko B (1996) Lupinus anatolicus - a new lupin species of the Old World. Genet Resour Crop Evol 43:109-117

Święcicki WK, Cowling WA, Buirchell BJ (2000) Databases and genetic resources evaluation in Lupinus collections. In: van Santen E, Wink M, Weissmann S, Römer P (eds) Lupin, an ancient crop for the new millennium. In: 9th international Lupin conference, Klink/Müritz, Germany, 20-24 June. International Lupin Association, Canterbury, New Zealand, pp 132-137

Święcicki WK, Wolko B, Naganowska B (2001) Lupinus anatolicus and L. $\times$ hispanicoluteus-morphological, biochemical and cytological characterization. In: Świecicki W, Naganowska B, Wolko B (eds) Broad variation and precise characterization-limitation for the future. XVI EUCARPIA genetic resources section workshop, Poznań, Poland, 16-20 May, pp 281-228

Święcicki W, Kroc M, Kamel K (2015) Lupins. In: De Ron AM (ed) Grain legumes. Handbook of plant breeding, vol 10. Springer Science + Business Media, New York, pp 179-218

UPOV (2004) Guidelines for the conduct of tests for distinctness, uniformity and stability-white lupin, narrow-leafed lupin, yellow lupin. Geneva. http://www.upov.int/edocs/ tgdocs/en/tg066.pdf. Accessed 16 June 2016

Wink M, Meißner C, Witte L (1995) Patterns of quinolizidine alkaloids in 56 species of the genus Lupinus. Phytochemistry $38: 139-153$ 